\title{
Meats are malady and millets are magical
}

\author{
Mahesh Shivananjappa \\ Yuvarajas College, India
}

Correspondence: Mahesh Shivananjappa,Yuvarajas College, Mysore, India, Tel + 91-9| I385 I262, Email Mayavishiva@gmail.com

Received: February 05, 2018 | Published: February 13, 2018

Copyright@ 2018 Shivananjappa. This is an open access article distributed under the terms of the Creative Commons Attribution License, which permits unrestricted use, distribution, and reproduction in any medium, provided the original author and source are credited.

\section{Introduction}

Cape Town is staring at severe water deficit in near future and is on war footing to save water to avoid "Day Zero" which is April $12 .{ }^{1}$ A recent UN report says by 2030 , world will be facing $40 \%$ water deficit which means world will not have enough water to meet its needs in just 12 years. $^{2}$ Water is one of our most critical resources which sustains agriculture and, thus, our food chain and ensures food and nutrition security. Much of today's agrarian problems stem from decreasing availability of freshwater. ${ }^{3}$

Agriculture accounts for $92 \%$ of the freshwater footprint of humanity; almost $35 \%$ relates to animal farming. Several fold more water is required for the production of animal products than that of plant products. The water footprint of any animal product is larger than the water footprint of crop products with equivalent nutritional value. The average water footprint per calorie for beef is 20 times larger than for cereals and starchy roots. The water footprint per gram of protein for milk, eggs and chicken meat is 1.5 times larger than for pulses. It requires 15000 liters of green water to produce $1 \mathrm{~kg}$ of meat compared to $1000-3000$ litres for rice. ${ }^{4}$

Furthermore, animal farming produces more greenhouse gas emissions than transport and make up as much as $80 \%$ of agricultural greenhouse gas (GHG) emissions. Beef generates 20 times more greenhouse gas emissions than beans, per gram of protein. Professor GidonEshel, at Bard College, New York, USA in his study on beefs environmental impacts, mentions when compared to staples like potatoes, wheat, and rice, the impact of beef per calorie is even more extreme, requiring 160 times more land and producing 11 times more greenhouse gases. Not only that the quantity of carbon dioxide emitted by humans eating diet with animal protein is doubled when compared to vegan diet. ${ }^{5}$

Moreover, Dr. Colin Campbell, author of The China Study, says diet with animal protein can turn on the cancer cell growth. Animals in the study that ate a diet made up of 20 percent animal protein had the strongest tumor growth rate, while animals fed with plant protein had no tumour growth [6]. It should also be noted that a high animal protein diet readily increases the activity of the $\mathrm{P} 450$ oxidase enzyme, which could be a regular source of ROS in addition to the mitochondrial electron transfer powerhouse which increases oxidative stress in the body causing several free radical mediated diseases and disorders. A study from Cleveland Clinic Foundation, Ohio, USA links the consumption of animal protein diet and several cardio-metabolic diseases through Trimethylamine N-oxide (TMAO). ${ }^{7}$
Consumption of meat / animal protein is hazard to human and environmental health. Curbing the worlds huge and increasing appetite for meat is essential to prevent catastrophic warming and thus avoid devastating climate change. Dr. Tim Benton of University of Leeds, UK says, "The biggest intervention people could make towards reducing their carbon footprints would not be to abandon cars, but to eat significantly less red meat." By choosing to eat more plant-based foods, you can drastically cut your carbon footprint, save precious water supplies, ensure that vital crop resources are fed to people, rather than livestock and lead a healthy life. ${ }^{5}$

A UN report, "Priority, Products, and Materials" concludes that, "A substantial reduction of environmental impacts would only be possible with a substantial worldwide diet change, away from animal products." All scientists warn of the need to move away from dependency on animals as a food source. But, for reasons unknown, requesting people to eat a balanced vegan diet or to reduce consumption of meat is taken as a personal affront to their very being and opens a real can of worms. Margaret Mead, a cultural anthropologist rightly said, "It is easier to change a man's religion than his diet." Humans think we are entitled to eat animals, regardless of the consequences on environment or our own health. ${ }^{8}$

With the wealth of available plant-based options available, it has never been easier to eat with the planet in mind. Of all the plant-based options available, cereals occupy the major proportions of vegetarian diet and are called staple foods. But both rice and wheat possess C3 photosynthetic pathways and hence require ample of water and Sunlight. ${ }^{9}$ Although their water and carbon footprints are far lesser than that of animal farming but still requires enormous water, fertilizers and pesticides to cultivate them and hence cannot grown in dry and arid region. Further rice with its inferior protein and fibre content has very high glycemic index which with increased consumption can lead to Insulin resistance, pre-diabetes and diabetes mellitus. Wheat has higher protein content, but its protein gluten is not tolerated well by large section of people and has a high glycemic index. ${ }^{10}$

Given this backdrop, Millets assumes the magical role of "The Saviour". Millets are small-grained cereals that are grown with little input mostly under unfavourable agricultural situations. Millets are highly climate resilient crop needing very little water and rainfall. ${ }^{11}$ Their highly efficient $\mathrm{C} 4$ photosynthetic pathways enable them to grow in harsh climatic condition with poor soil fertility and are boon 
for vast dry land area. Unlike rice and wheat, no millets attract any pest during their growth as well during their storage. Wheat is thermal sensitive crop which might disappear with projected 2 degree rise in temperature. Rice has very high carbon foot print amongst all the food crops emitting Methane from water-drenched rice fields. While season specific wheat and rice might provide only food security, allseason crop Millets provide, food, fodder, nutrition, health, livelihood and ecological securities. ${ }^{12}$

Barnyard millet (Echinochloafrumentacea), Finger millet (Eleusinecoracana), Foxtail millet (Setariaitalica), Kodo millet (Paspalumscrobiculatum), Little millet (Panicum miliare), Pearl millet (Pennisetumamericanum), Proso millet (Panicum miliaceum), are the important millets which are cultivated largely in the Asian and African countries. Fonio (Digitariaexilis) and Tef (Eragrostictef) are specific to Nigeria and Ethiopia respectively. ${ }^{13}$

Millets are miraculous in their nutrition content. Millets are superior to rice in their protein content and are equal to wheat without gluten. Their fibre content is 3 to 5 times more than the widely promoted rice and wheat. This increased fibre content is one of the reasons millets to have very low glycemic index compared to rice and wheat and thus beneficial in weight reduction, insulin resistance and diabetes mellitus. The high fibre content of millets acts as pre-biotics or gut fertilizers and thus helps to maintain healthy gut microbiome. ${ }^{14}$

Millets are also rich in phytochemical such as alkaloids, terpenoids, tannins, phenolic compounds and flavonoids. These phytochemicals have both complementary and overlapping mechanism action inducing detoxifying enzymes, scavenging free-radicals, inhibiting nitrosoamine formation, blocking formation of neoplastic agents, and diluting carcinogens, among others. ${ }^{15-17}$

Although millets are nutritionally superior to rice and wheat, their utilization is not wide spread. The major constraints are the antinutritional factors present in their fibrous seed coat, coloured pigments, astringent flavour and poor keeping quality of the processed products. Treatments like pearling, de-branning, soaking, sprouting, malting and other chemical treatments can overcome some of these constraints and improve nutritional quality and consumer acceptability. ${ }^{15-17}$

At present, by consuming animal protein we are eating ourselves to disease and death. Switching to plant-based diets, especially involving millets, are the only viable answer to the looming environmental and health catastrophe. Its either millets or tablets (pills); millets or malady. Millets are the future of food and farming. ${ }^{18}$

\section{References}

1. https://edition.cnn.com/2018/01/24/africa/cape-town-water-crisis-trnd/ index.html

2. Connor R. The United Nations world water development report 2015 : water for a sustainable world. UNESCO Publishing. 2015;1.

3. https://www.the-scientist.com/?articles.view/articleNo/31068/title/ Opinion--The-Water-Deficit/

4. Hoekstra AY, Mekonnen MM. The water footprint of humanity. Proc Natl Acad Sci India. 2012;109(9):3232-3237.

5. https://www.theguardian.com/environment/2014/jul/21/giving-up-beefreduce-carbon-footprint-more-than-cars

6. https://www.cancertutor.com/china-study/

7. Tang WW, Hazen SL. Microbiome, trimethylamine N-oxide, and cardiometabolic disease. Transl Res. 2017;179:108-115.

8. http://www.abc.net.au/news/2014-04-28/hamad-meat-the-hidden-culpritof-climate-change/5414894

9. http://www.cropsreview.com/c3-plants.html

10. Newberry C, McKnight L, Sarav M, et al. Going gluten free: the history and nutritional implications of today's most popular diet. Curr Gastroenterol Rep. 2017;19(11):54.

11. http://www.sahajasamrudha.org/images/Millet\%20Booklet.pdf

12. Lobell DB, Gourdji SM. The influence of climate change on global crop productivity. Plant Physiol. 2012;160(4):1686-1697.

13. Jaybhaye RV, Pardeshi IL, Vengaiah PC, et al. Processing and technology for millet based food products: a review. Journal of Ready to Eat Food. 2014;1(2):32-48.

14. Chandel G, Meena RK, Dubey M, et al. Nutritional properties of minor millets: neglected cereals with potentials to combat malnutrition. Curr Sci. 2014;107(7):1109-1111.

15. Rathore S, Singh K, Kumar V. Millet Grain Processing, Utilization and Its Role in Health Promotion: A Review. International Journal of Nutrition and Food Sciences. 2016;5(5):318-329.

16. Sarita SE. Potential of millets: nutrients composition and health benefits. J Sci Innov Res. 2016;5:46-50.

17. Saleh AS, Zhang Q, Chen J, et al. Millet grains: nutritional quality, processing, and potential health benefits. Compr Rev Food Sci Food Saf. 2013;12(3):281-295.

18. http://www.swaraj.org/shikshantar/millets.pdf 